\title{
Virulence gene(s) Gamut of Enteropathogenic Escherichia coli (EPEC) and Shiga Toxin-Producing Escherichia coli (STEC) in Piglets with or without Diarrhoea in Mizoram (India)
}

\author{
J.L. Kataria*, T.K. Datta and P. Roychoudhury \\ Department of Veterinary Public Health and Epidemiology, C.V.Sc \& A.H., Selesih, \\ Aizawl, Mizoram - 796014, India \\ *Corresponding author
}

A B S T R A C T

\begin{tabular}{|l|}
\hline Ke y w o r d s \\
$\begin{array}{l}\text { Growth, Yield, } \\
\text { Quality, TSS: acid } \\
\text { ratio. }\end{array}$ \\
\hline Article Info \\
\hline $\begin{array}{l}\text { Accepted: } \\
\text { 17 September } 2017 \\
\text { Available Online: } \\
\text { 10 November } 2017\end{array}$ \\
\hline
\end{tabular}

\section{Keywords}

Entero pathogenic Escherichia coli (EPEC) and Shiga toxin-producing Escherichia coli (STEC) are food-borne pathogens of public health concern. EPEC causes infantile watery diarrhoea and is more prevalent in developing countries than in the industrialized country. STEC, conversely are responsible for both outbreaks and sporadic cases of human diseases, ranging from mild diarrhea to hemorrhagic colitis (HC) and life-threatening hemolytic uremic syndrome (HUS) leading to kidney failure and death. Various transmission routes of EPEC and STEC have been identified, such as contaminated food and water, animal contact, person to person contact etc. Animals, such as cattle, wildlife species and swine are recorded as important reservoirs.

\section{Introduction}

Entero pathogenic Escherichia coli (EPEC) and Shiga toxin-producing Escherichia coli (STEC) are food-borne pathogens of public health concern (Ercoli et al., 2015). EPEC causes infantile watery diarrhoea and is more prevalent in developing countries than in the industrialized country (Baliere et al., 2015). STEC, converselyare responsible for both outbreaks and sporadic cases of human diseases, ranging from mild diarrhea to hemorrhagic colitis (HC) and life-threatening hemolytic uremic syndrome (HUS) leading to kidney failure and death (Baranzoni et al., 2016).
Various transmission routes of EPEC and STEC have been identified, such as contaminated food and water (Kaspar et al., 2010), animal contact (Keen et al., 2007), person to person contact (Rowe et al., 1993) etc. Animals, such as cattle, wildlife species (Singh et al., 2015) and swine (Tseng et al., 2014) are recorded as important reservoirs.

\section{Materials and Methods}

A total of 100 rectal swabs from piglets (0-3 months) with or without diarrhoea were collected from different places of Mizoram, 
India. All the swabs were processed for isolation and identification of E.coli (Ewing, 1986). All the isolates were subjected to serotyping based upon somatic antigens and were further assessed by polymerase chain reaction (PCR) assay for the presence of putative virulence gene(s)(eae $\mathrm{A}$, hlyA, stx and $s t x_{2}$ ) (Paton and Paton, 1998) and STEC autoagglutinating adhesion gene (saa) (Paton and Paton, 2001). All the isolates were subjected to antimicrobial sensitivity assay by disc diffusion method using 14 commonly used antimicrobial agents (Bauer et al., 1966).

A total of $254 E$. coli were isolated, of which $55(21.65 \%)$ isolates were found to be positive for at least one virulence gene (Table 1). As depicted in Table 1, a total of 2 $(0.78 \%), 9(3.54 \%)$ and $4(1.54 \%)$ isolates were positive forstx 1, stx $_{2}$ and eaeA gene, respectively. A total of $40(15.74 \%)$ isolates were carrying multiple genes. Four $(1.56 \%)$, isolates in combination of $s t x_{1}$ and $s t x_{2}$ genes were recorded as positive for saa gene. Based upon the virulence genes profile, 34 (12.20\%) and $21(8.27 \%)$ isolates were characterized as
STEC and EPEC, respectively. Among STEC isolates, stx $2(54.5 \%)$ was predominant over by $\operatorname{stx}_{1}(14 \%)$, which was in accordance to the finding of earlier workers (Islam et al., 2016; Bandhopadhyay et al., 2012). Isolation of $s t x_{2}$ E. coli positive from piglets may be a public health concern. saa and eaeA genes appears to be mutually exclusive to each other and our results was also in accordance to earlier workers (Miko et al., 2014; Paton et al., 2001). Similarly, there was no association between saa and hlyA gene, which was also in corroboration to the result of Beraldo et al., (2014). However, the present result is in contrast to earlier workers (Olivera et al., 2007; Wani et al., 2004), who reported the mutually inclusiveness of saa and hlyA gene, which can be explained by the high variability of the large STEC plasmids (Brunder et al., 1997) and it may also be possible that hlyA gene is not located on the same plasmid with saa. To the best of our knowledge, this is the first report on detection of saagene from piglets with or without diarrhoea in India.

Table.1 Virulence gene(s) profile and somatic type of $E$. coli isolated from piglets of Mizoram, India

\begin{tabular}{|c|c|c|c|c|c|}
\hline \multirow[t]{2}{*}{ Sl.No } & \multirow[t]{2}{*}{ Virulence gene(s) } & \multirow{2}{*}{$\begin{array}{l}\text { Serotype and number of strains of the } \\
\text { isolates (Figures in parenthesis indicating } \\
\text { the number) }\end{array}$} & \multicolumn{2}{|c|}{ Number of isolates } & \multirow[t]{2}{*}{ Total N (\%) } \\
\hline & & & $\begin{array}{l}\text { With diarrhoea } \\
\qquad \mathrm{N}(\%)\end{array}$ & $\begin{array}{c}\text { Without } \\
\text { diarrhoea } \mathrm{N}(\%)\end{array}$ & \\
\hline 1. & stx $_{1}$ & O24 (1), O174 (1) & $1(0.81 \%)$ & $1(0.75 \%)$ & $2(0.78 \%)$ \\
\hline 2. & $s t x_{2}$ & $\begin{array}{l}\mathrm{O} 24(2), \mathrm{O} 75(2), \mathrm{O} 119(3), \mathrm{O} 120(1), \mathrm{UT} \\
(1)\end{array}$ & $6(4.9 \%)$ & $3(2.2 \%)$ & $9(3.54 \%)$ \\
\hline 3. & $s t x_{1}+s a a$ & $\mathrm{O} 24(2)$ & - & $2(1.5 \%)$ & $2(0.78 \%)$ \\
\hline 4. & $s t x_{1}+s t x_{2}+s a a$ & O24 (2) & $1(0.81 \%)$ & $1(0.75 \%)$ & $2(0.78 \%)$ \\
\hline 5. & $s t x_{1}+s t x_{2}$ & O119 (1), O161 (1) & - & $2(1.5 \%)$ & $2(0.78 \%)$ \\
\hline 6. & $s t x_{2}+e a e \mathrm{~A}$ & $\begin{array}{l}\text { O2 (2), O24 (1), O51 (1), O97 (1), O132 } \\
(1), \text { O142 (1) }\end{array}$ & $3(2.4 \%)$ & $4(3.0 \%)$ & $7(2.75 \%)$ \\
\hline 7. & stx $x_{2}+h l y \mathrm{~A}$ & $\mathrm{O} 24(1)$ & & $1(0.75 \%)$ & $1(0.39 \%)$ \\
\hline 8. & stx $_{2}+e a e \mathrm{~A}+h l y \mathrm{~A}$ & $\begin{array}{l}\text { O2 (1), O69 (1), O75 (1), O119 (3),O159 } \\
(1), \text { O165 (1), UT (1) }\end{array}$ & $5(4.0 \%)$ & $4(3.0 \%)$ & $9(3.54 \%)$ \\
\hline 9. & eaeA & O60 (1), O75 (1), O141 (1), UT (1) & $2(1.6 \%)$ & $2(1.5 \%)$ & $4(1.57 \%)$ \\
\hline 10. & $e a e \mathrm{~A}+h l y \mathrm{~A}$ & $\begin{array}{l}\text { O56 (1), O60(1), O103 (1), O119 (10), } \\
\text { O132 (1), O162 (1), O163 (1), O168 (1) }\end{array}$ & $9(7.30 \%)$ & $8(6.0 \%)$ & $17(6.69 \%)$ \\
\hline & & TOTAL & $27(22.13 \%)$ & $28(21.21 \%)$ & $55(21.65 \%)$ \\
\hline
\end{tabular}


All the 55 EPEC/ STEC isolates from piglets carrying virulence gene(s) were belonged to 23 different ' $O$ ' serogroups (Table 1).

O119 was the predominant serotype which belonged to one of the 12 ' $\mathrm{O}$ ' serogroups of EPEC recognised by World Health Organisation (WHO, 1987). The other serotypes identified in this study were not reported earlier workers in India, nonetheless, as several new serotypes of $E$. coli such as O178 (Mika et al., 2014) and O104 (Frank et al., 2011) are being established as potential pathogens for human and animals.

All the 55 EPEC / STEC isolates showed $100 \%$ drug resistance to bacitracin, methicillin and novobiocin. Cefazolin and ofloxacin for EPEC and cefixime, gatifloxacin and cefazolin for STEC were the better antimicrobial agents in terms of sensitivity. Multiple drug resistance in EPEC and STEC strains may result from spread of genetic elements, such as plasmids, prophages or transposons, allowing horizontal transfer within and between bacterial species, predominantly in environments such as the gut micro-biome (Amaechi et al., 2015). In Mizoram, pig rearing is the most common practice and pork is the major source of protein. Emergence of multi drug resistant EPEC and STEC isolates in high proportion indicates that they may act as an important reservoir posing a possible threat to public health and may complicate future therapeutic options.

\section{Acknowledgement}

The author are thankful to Dean, College of Veterinary Science and Animal Husbandry, Central Agricultural University, Selesih, Aizawl, Mizoram, India for providing necessary funds and facilities to carry out the investigation.

\section{References}

Amaechi. N., Abbey, S.D. and Achi, O.K. 2015. Int.J.Curr.Microbiol.App.Sci(2): 834-842

Baliere, C., Rincé, A., Blanco J., Dahbi, G., Harel, J., Vogeleer, P., Giard, J.C., Kurkdjian, P.M. and Gourmelon,M. 2015. Prevalence and Characterization of

Bandyopadhyay, S., Lodh, C., Rahaman, H., Bhattacharya, D., Bera, A.K., Ahmed, F.A., Mahanti, A., Samanta., I., Mondal, D.K., Bandyopadhyay, S., Sarkar, S., Dutta, T.K., Maity, S., Paul, V., Ghosh, M.K., Sarkar, M., and Baruah, K.K. (2012). Characterization of shiga toxin producing (STEC) and enteropathogenic Escherichia coli (EPEC) in raw yak (Poephagus grunniens) milk and milk products. Res. Vet. Sc.93:604-610

Baranzoni, G.M.,Fratamico, P.M., Gangiredla, J., Patel, I., Bagi, L.K., Delannoy, S., Fach, P.,Boccia, F., Anastasio A. and Pepe T. (2016).Characterization of Shiga Toxin Subtypes and Virulence Genesin Porcine Shiga Toxin-Producing Escherichia coli. Front. Microbiol. 7:574.doi: 10.3389/fmicb.2016.00574

Bauer, A.W., Kirby, W.M., Sherriz, J.C. and Tuck, N. 1966. Antibiotic susceptibility testing by standardized single disc method. Am J ClinPathol, 45: 493-496.

Beraldo, L.G., Borges, C., Maluta, R.P., Cardozo, M.V., Rigobelo, E.C., Avila, F. A. 2014.Detection of Shiga toxigenic (STEC) and enteropathogenic (EPEC) Escherichia coli in dairy buffalo. Vet. Microbiol.

http://dx.doi.org/10.1016/j.vetmic.2014. 01.023 .

Brunder W., Schmidt H. and Karch H. 1997. EspP, a novel extracellular serine protease of enterohaemorrhagic 
Escherichia coli O157:H7 cleaves human coagulation factor. Vet. Mol. Microbiol., 24: 767-778.

Ercoli, L., Farneti, S., Ranucci, D., Scuota, S. and Branciari R. 2015. Role of verocytotoxigenic Escherichia coliin the swine production chain. Italian Journal of Food Safety. 4:5156.

Ewing, W. H. (1986). The genus Escherichia, p. 93-122. In P. R. Edwards and W. H Ewing (ed), Edwards and Ewing's identification of Enterobacteriaceae, $4^{\text {th }}$ ed. Elsevier Science Publishing Co Inc., New York, N. Y.

Frank, C., Werber, D., Cramer, J. P., Askar, M., Faber, M., An Der Heiden, M., et al., (2011). Epidemic profile of Shigatoxin-producing Escherichia coli O104:H4 outbreak in Germany. $N$. Engl. J. Med. 365, 1771-1780. doi: 10.1056/NEJMoa1106483

Kaspar C, Doyle ME, Archer J. 2011. White paper on non-O157:H7 Shiga-toxin producing $E$. coli from meat and nonmeat sources. http://fri.wisc.edu/docs/ pdf/FRI_Brief_NonO157STEC_4_10. pdf

Kaspar, C., Doyle, M.E. and Archer, J. 2010. White paper on non-O157:H7 Shiga toxin-producing $E$. coli from meat and non-meat sources. 2010

Keen J.E., Durso L.M. and Meehan, T.P. 2007. Isolation of Salmonella enterica and Shiga-toxigenic Escherichia coli O157 from feces of animals in public contact areas of United States zoological parks. Applied and Environmental Microbiology. 73:362365.

Miko, A., Rivas, M., Bentancor, A., Delannoy, S., Fach, P. and Beutin, L. 2014. Emerging types of Shiga toxinproducing E. coli (STEC) O178 present in cattle, deer, and humans from Argentina and Germany. Front. Microbiol. 6:1356
Oliveira, M.G., Feitosa Brito, J.R., Carvalho, R.R., Guth, B.E.C., Gomes, T.A.T., Vieira, M.A.M., Kato, M.A.M.F., Ramos, I.I., Vaz, T.M.I. and Irino, K. (2007). Water buffaloes (Bubalus bubalis) identified as an important reservoir of Shiga toxin-producing Escherichia coli in Brazil. Appl. Environ. Microbiol. 73: 5945-5948.

Paton, A.W., Srimanote, P., Woodrow, M.C., and Paton, J.C. (2001). Characterization of saa, a novel autoagglutinating adhesin produced by locus of enterocyte effacement-negative shiga-toxigenic Escherichia coli strains that are virulent for humans. Infect. Immun. 69, 69997009.

Paton, J.C., and Paton, A.W. (1998). Pathogenesis and diagnosis of Shiga toxin-producing Escherichia coli infections. Clin. Microbiol. Rev. 11, 450-479.

Rowe, P.C., Orrbine, E., Lior, H., Wells, G.A. and McLaine, P.N. 1993. Diarrhoea in close contacts as a risk factor for childhood haemolytic uraemic syndrome. Epidemiology and Infection. 110:9-16.

Shiga Toxin - Producing and Enteropathogenic Escherichia coli in Shellfish-Harvesting areas and their Watersheds. Front. Microbiol. 6:1356

Singh, P., Sha, Q., Lacher, D. W., Del Valle, J., Mosci, R. E., Moore, J. A., et al., (2015). Characterization of enteropathogenic and Shiga toxinproducing Escherichia coli in cattle and deer in a shared agroecosystem. Front. Cell. Infect. Microbiol.5:29. doi: 10.3389/fcimb.2015.00029

Tseng, M., Fratamico, P. M., Manning, S. D., and Funk, J. A. (2014). Shiga toxin producing Escherichia coli in swine: the public health perspective. Anim. Health Res. Rev. 15, 1-13. doi: $10.1017 / \mathrm{S} 1466252313000170$ 
Wani, S.A., Samanta, I., Bhat, M.A., and Nishikawa, Y. (2004). Investigation of Shiga toxin- producing Escherichia coli in avian species in India. Lett Appl Microbiol, 39: 389-94.
WHO (1987). Program for Control of Diarrhoeal Diseases. Manual for Laboratory Investigation of Acute Enteric Infections. Geneva: World Health Organization.

\section{How to cite this article:}

Kataria, J.L., T.K. Datta and Roychoudhury, P. 2017. Virulence Gene(S) Gamut of Entero Pathogenic Escherichia coli (EPEC) and Shiga Toxin-Producing Escherichia coli (STEC) in Piglets with or without Diarrhoea in Mizoram (India). Int.J.Curr.Microbiol.App.Sci. 6(11): 1983-1987. doi: https://doi.org/10.20546/ijcmas.2017.611.235 